\title{
MINERAL RESOURCE POTENTIAL OF THE POND MOUNTAIN AND POND MOUNTAIN AD DITION ROADLESS AREAS, CARTER COUNTY, TENNESSEE
}

By

\author{
W. R. Griffitts, U.S. Geological Survey, \\ and R. F. Bitar \\ and \\ M. L. Chatman, U.S. Bureau of Mines
}

\section{STU DIES RELATED TO WILDERNESS}

Under the provisions of the Wilderness Act (Public Law 88-577, September 3, 1964) and related acts, the U.S. Geological Survey and the U.S. Bureau of Mines have been conducting mineral surveys of wilderness and primitive areas. Areas officially designated as "wilderness," "wild," or "canoe" when the act was passed were incorporated into the National Wilderness Preservation System, and some of the m are presently being studied. The act provided that areas under consideration for wilderness designation should be studied for suitability for incorporation into the Wilderness System. The mineral surveys constitute one aspect of the suitability studies. The act directs that the results of such surveys are to be made available to the public and be submitted to the President and the Congress. This report discusses the results of a mineral survey of the Pond Mountain Roadless Area (8-035) and the Pond Mountain Addition Roadless Area (8-273), Cherokee National Forest, Carter County, Tennessee.

\section{MINERAL RESOURCE POTENTIAL SUMMARY STATEMENT}

The U.S. Geological Survey and U.S. Bureau of Mines studied the Pond Mountain and Pond Mountain Addition Roadless Areas, Carter County, Tennessee, to evaluate the mineral resource potential of the areas. The areas are on the northwestern flank of the Blue Ridge and are underlain by crystalline rocks of Preca m brian age and clastic rocks and dolomite of Cambrian age.

A small a mount of residual $\mathrm{m}$ anganese and iron was mined near the northern boundary of the Pond Mountain Roadless Area. Iron prospects and thorium prospects in Precambrian rock were opened southeast of the area, but no ore has been mined from these deposits within the roadless area. The resource potential is low for $\mathrm{m}$ anganese and iron in $\mathrm{sm}$ all areas in the northern part of the Pond Mountain Roadless Area.

The Precambrian rocks contain abundant tin, niobium, tungsten, beryllium, and a few other metals, which indicate that the rocks have been mineralized, most strongly in the Pond Mountain Addition Roadless Area. Most of the Pond Mountain Addition Roadless Area has low to high resource potential for tin, tungsten, and niobium. A small part of the Pond Mountain Roadless Area has low resource potential for tin, tungsten, and niobium. Beryllium, molybdenum, zinc, topaz, and fluorite might be recovered as byproducts of the mining of tin, tungsten, or niobium.

\section{INT RO D U CTIO N}

The roadless areas encompass about $10 \mathrm{sq} \mathrm{mi}$ in the Cherokee National Forest in eastern Tennessee (fig. 1). They are in Carter County, about $7 \mathrm{mi}$ southeast of Elizabethton and are near the TennesseeNorth Carolina boundary. The area is heavily wooded and rises southward from an altitude of about $2,000 \mathrm{ft}$ near Lake Watauga to about 4,000 ft in the Blue Ridge Mountains. Public roads surround the roadless areas, and they are crossed by the Appalachian Trail.

Geoche mical fieldw ork was done in 1980 by K. A. Duttweiler, W. R. Griffitts, and J. W. Whitlow of the U.S. Geological Survey. Prospects were examined and rocks and sediment sa mpled in $1981-83$ by R. F. Bitar, P. T. Behum, and R. W. Ham mack of the Bureau of Mines, who also mapped a shear zone that crosses Big Branch a short distance south of Pond Mountain. Supplementary fieldwork was done by M. L. Chatman. The broader features of the geology are from King and Ferguson (1960).
Little mining has been done in the roadless areas. A few prospects for radioactive $m$ aterials were opened in the Precambrian rocks in and alongside the roadless areas in the 1950 's, and iron prospects were opened in veins in the same general areas many years earlier. Manganese and iron were mined fro $\mathrm{m}$ residual deposits along the northern and northwestern edge of the areas.

The Federal government holds surface rights of about 99 percent of the roadless areas and mineral rights of about 54 percent. The rest of the rights are privately held. The U.S. Bureau of Land Manage ment has issued oil and gas leases covering about 21 percent of the roadless areas or about 39 percent of the area for which the government holds mineral rights. In 1983, there were no active permits to prospect for solid minerals on govern ment land.

\section{MININ G A CTIVITY}

No mines or quarries were active in the vicinity of the roadless areas during the investigations in 


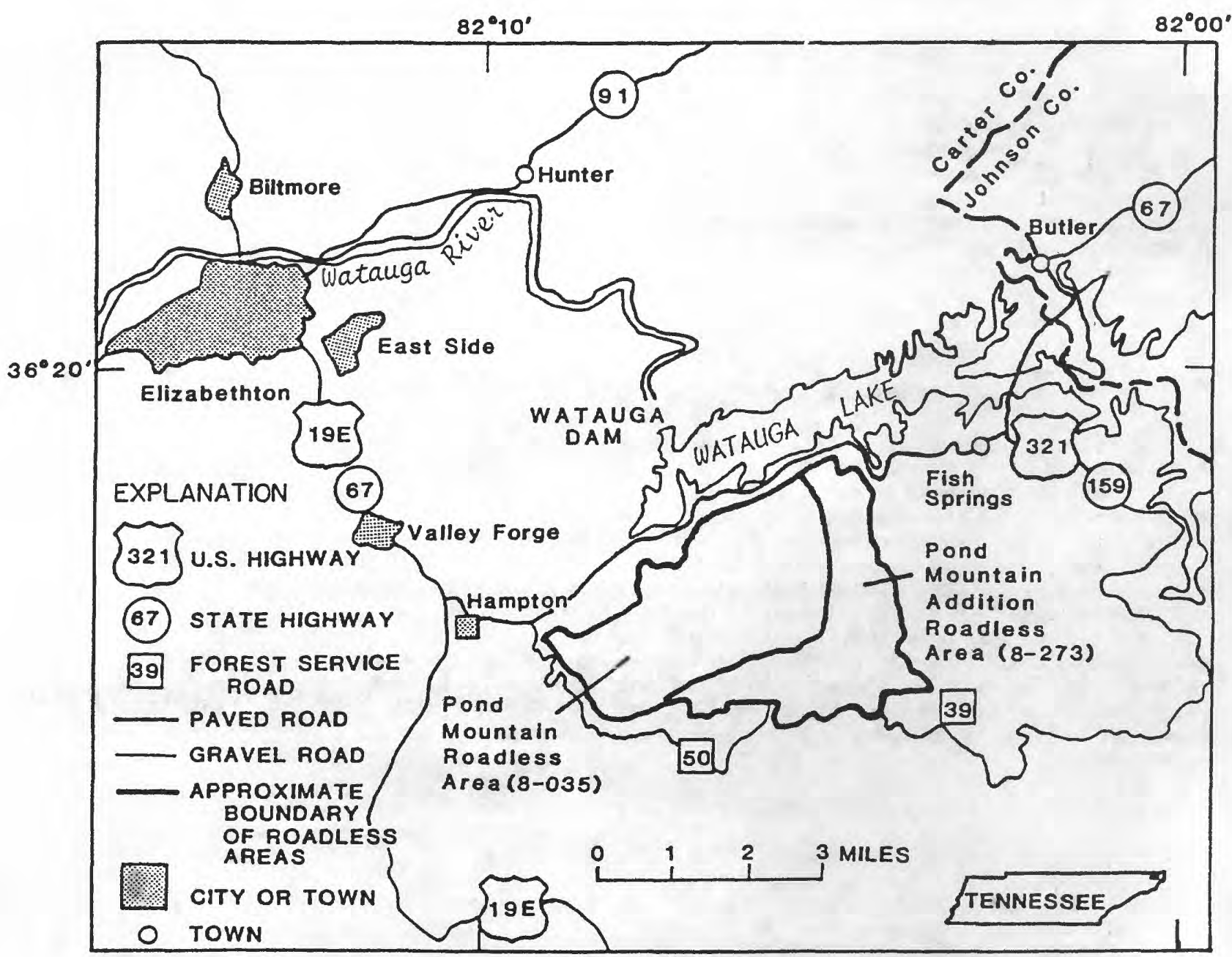

Figure 1. - Index map showing location of the Pond Mountain and Pond Mountain Addition Roadless Areas, Carter County, Tennessee. 
1980-83. Prospecting and small-scale mining has been mainly of residual lateritic fron and manganese deposits and of veins that contain black iron oxides, uraniu $\mathrm{m}$, and thorium (fig. 2).

\section{GEOLOGY}

The Pond Mountain area is underlain by a sequence of sedimentary rocks of early Paleozolc age that overlies Preca $\mathrm{m}$ brian base $\mathrm{m}$ ent rocks.

The basement rocks are exposed in the southeastern part of the roadless areas and consist of Precambrian granitic rocks ranging in composition from granite to quartz monzonite to granodiorite, and $s m a l l e r$ amounts of micaceous metamorphic rocks. Coarse, massive, pink granite is predominant, but $\mathrm{small}$ bands of finer grained red granite and finegrained porphyritic granite are within the coarse granite, as are some steeply dipping phyllite or phyllonite layers.

01der base ment rocks that have been thrust over the granitic rocks consist of a complex of quartz monzonite and granite that has been highly sheared, resulting in flaser gneiss, phyllonite, and mylonite. In addition, these sheared rocks were cut by pegmatites, quartz veins, and dikes. The metamorphis $m$ forming flaser gneiss, mylonite, and phyllite was plutonic and took place in Precambrian time. One shear zone in granitic rock was studied in detail. The thrusting, folding, and local shearing occurred after metamorphism in late Paleozoic time (King and Ferguson, 1960).

The sedimentary rocks lie unconformably on the base ment rocks. They include, at the base, the thick Chilhowee Group of clastic rocks of Late Proterozoic to Early Cambrian age, overlain by a carbonate sequence, the Shady Dolomite.

The lowermost unit of the Chilhowee Group is the Unicoi Formation. It consists of thick-bedded quartzite, partly arkosic and conglomeratic, interbedded with so me thin-bedded arkose.

The Hampton Formation, overlying the Unicoi Formation, is generally thought of as a shaly interval between the more sandy or quartzitic Unicoi and Erwin Formations below and above, respectively. It is composed mainly of dark-gray to greenish-gray shale and interbedded siltstone and arkosic sandstone in the lower part, and vitreous quartzite in the upper part.

The Erwin Formation is the uppermost unit of the Chilhowee Group and includes four members, which for this report have been grouped. They consist of interlayered white vitreous quartzite, dark ferruginous quartzite, siltstone, and shale. The white quartzite beds constitute a relatively $\mathrm{small}$ part of the formation but serve to distinguish it from the otherwise similar underlying Ha mpton Form ation.

The Shady Dolomite of Early and Middle Cambrian age overlies the Chilhowee Group. It consists mostly of blue-gray and white dolomite but includes small amounts of limestone and a few beds of shale in the upper part. Dolomite of the Shady has been jointed, brecciated, and recrystallized. In many places, not shown on the map, the Shady Dolomite is covered by a waxy brown-buff residual clay formed by weathering of the dolomite. Concretions or lumps of $\mathrm{m}$ anganese and iron oxides are in residuum overlying the lower part of the Shady Dolomite.

\section{GE O CHE MIST R Y}

Concentrates of nonmagnetic heavy minerals panned from each strea $\mathrm{m}$ in or near the roadless areas were analyzed mineralogically and spectrographically; most concentrates collected in the area of Preca $m$ brian rock contain concentrations of ore metals or minerals, and a few sa mples collected in the area of Paleozoic rocks contained ore metals or minerals (Duttweller and others, 1987). Tin values exceed 1,000 $\mathrm{ppm}$ in all samples except one from the Precambrian rocks, niobium values are $200-2,000 \mathrm{ppm}$, tungsten 200-2,000 ppm, beryllium 10-200 pp m, and molybdenum 10-20 ppm. Most of these ele ments and fluorite and topaz are found in most of the world's leading tin-producing districts (Taylor, 1979).

The abundance of tin, beryllium, niobium, and tungsten associated with small amounts of molybdenum and zinc provide clear evidence that the Precambrian rocks in the study area have been mineralized. Topaz and fluorite in the heavy-mineral concentrates also indicate mineralization that is geochemically similar to that which formed tin and tungsten ores in $m$ any parts of the world (Taylor, 1979). Samples that are rich in niobium and tungsten are most abundant from the southeastern part of the study area, including samples containing topaz or fluorite. These higher values probably indicate that the mineralization was stronger in that general area. Columbite and wolframite, probably the main hosts of niobium and tungsten, respectively, do not survive transport over very long distances, so they may have disappeared from the sediment as it was reworked in the western and northern streams. More durable cassiterite, as well as phenakite, chrysoberyl, and some other beryllium minerals could persist for much longer distances, which would result in more widely dispersed tin and beryllium.

\section{MIN ER AL D EP OSITS}

$\mathrm{Sm}$ all residual manganese and fron deposits are known near the northern part of the roadless areas. The ore deposits consist of lumps of hydrous iron or $m$ anganese oxides embedded in tan to light-brown clay. These bodies are a residuum of weathering of the Shady Dolomite and are restricted to re mnants of the Harrisburg or Valley Floor peneplain.

Black tron ore is exposed in the Precambrian rocks near, but not in, the roadless areas (Bayley, 1923). Possibly related uraniu $m$ and thorium prospects were opened in, as well as near, the roadless areas. No minable deposits were found.

The investigations leading to this report have provided evidence of previously unknown mineralization with niobium, tin, tungsten, and beryllium. The veins of $m$ agnetite and black he $m$ atite in the Precambrian rocks and veins containing rare earths very likely were formed during the same mineralization. Although minor as iron resources, these veins are of use in indicating the extent of the mineralized area. These little known deposits of lithophile elements are speculative sources of tin, niobium, and tungsten. As such, they are more attractive exploration targets than the previously known residual iron and $m$ anganese deposits, which are known to be rather $\mathrm{small}$. They are, accordingly, discussed in more detail. 


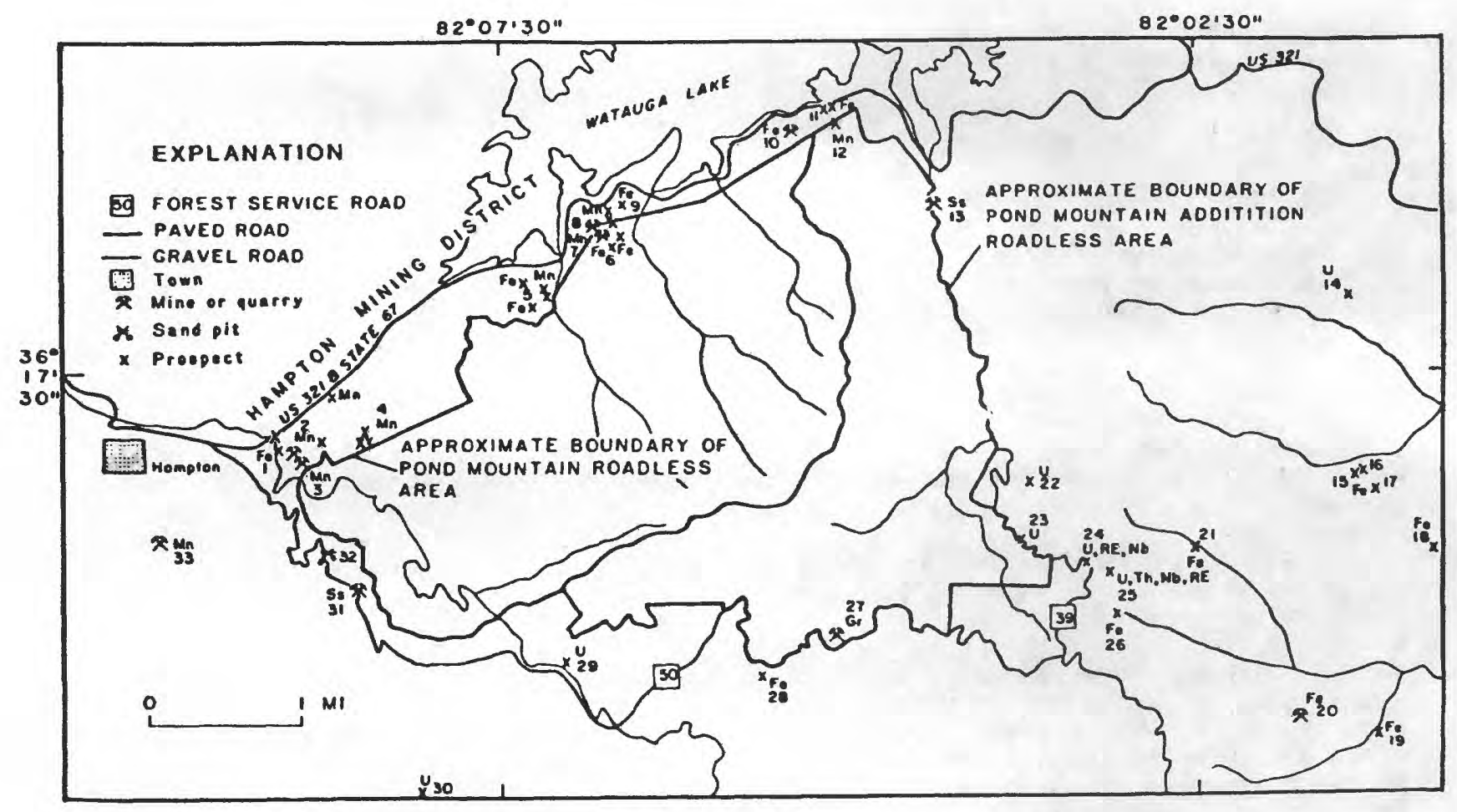

1. Unnamed Fe prospect

2. Carden $M n$ prospect

3. Grindstaff $M n$ prospect

4. Teaster and Ray Mn prospect

5. Unnamed $\mathrm{Fe}$ and Mn prospect

6. Cardens Bluff $\mathrm{Fe}$ prospect

7. Cardens Bluff Fe mine

8. Cardens Bluff $\mathrm{Mn}$ mine

9. Virginia Iron, Coal, and Coke Co. (C. A. Blevins) $\mathrm{Fe}, \mathrm{Mn}$ prospects

10. Lim onite Ore Bank, Fe

11. Unnamed Fe ore prospect

12. Unnamed Mn prospect

13. Sandstone quarry

14. Row Branch U prospect

15. Black Bear Fe prospect

16. Blacks Fe prospect

17. Rabbit Station Fe prospect
18. Mays Ridge Fe prospect

19. Lunsford Fe prospect

20. Finney and Teegarden $\mathrm{Fe}$ mine

21. Mtller Fe prospect

22. Goodwin Field Branch U prospect

23. Laurel Gap U prospect

24. Wagener and $\mathrm{McH}$ one $U$ prospect

25. Walnut Mountain $\mathrm{U}, \mathrm{Th}, \mathrm{Nb}, \mathrm{RE}$ prospect

26. Unnamed Fe prospect

27. Granite quarry

28. Whitehead Fe prospect

29. Dennis Cove U prospect

30. Big Flats Branch U prospect

31. Sandstone quarry

32. Sand pit

33. Cedar Hill Mn mine

Figure 2.-M ap showing mines and prospects in the Pond Mountain and Pond Mountain Addition Roadless Areas and vicinity. M n, manganese; U, uranium; N b, niobium; Ss, sandstone; Fe, Iron; Th, thorium; RE, rare earths; Gr, granite. 
Residual $\mathrm{m}$ anganese and iron deposits

The roadless areas lie along the southeastern margin of the Hampton mining district. Minor amounts of brown iron ore and hard and soft $m$ anganese ores have been produced from residual clay of the Shady Dolomite. Most iron production took place during the middle to late 1800's and early 1900 's. Many mines originally opened for fron were subsequently reopened for manganese production during World Wars I and II and during the Federal strategic stockpile purchase program between 1953 and 1959.

Individual $\mathrm{m}$ anganese and iron deposits in the region are small and generally underlie less than 2 acres; most yielded no more than a few hundred tons of ore. The size and shape of the deposits in the residuum are irregular. Many are lenses that pinch out laterally but may be parts of series of lenses. Some areas that appear suitable for $\mathrm{m}$ anganese and iron oxide accumulation contain no deposits. Although the Shady Dolomite is believed to be the source of the manganese and iron, no unusual concentrations of $m$ anganese have been found in unweathered dolomite (King and others, 1944).

$\mathrm{H}$ ard oxides, mainly psilomelane in nodules, are the most abundant manganese ore; soft oxides such as pyrolusite and wad are also present. The iron minerals consist mainly of limonite and goethite. Higher grade deposits of $\mathrm{m}$ anganese oxides (about 40 percent $\mathrm{Mn}$ ) and iron oxides (about 50 percent $\mathrm{Fe}$ ) are more or less separate from one another. However, the lower grade deposits of either $m$ anganese or iron com monly contain several percent of the other metal. Manganese deposits in the Shady Dolomite have cobalt concentrations of as much as 1 percent (King and others, 1944), probably in lithiophorite. The highest cobalt value noted in a sample obtained near the study area is 0.10 percent in manganese ore from the Cardens Bluff mine (Bitar and others, 1985).

The parts of the study area with the largest deposits are along the lower slopes and base of the northwestern side of Pond Mountain where crests of low ridges representing the remnants of formerly extensive terraces are at two levels: between 2,080 and 2,200 ft in altitude, and between 2,260 and 2,380 $\mathrm{ft}$ in altitude. Smaller manganese deposits are on a series of smaller terrace remnants at a third level between 2,380 and 2,480 ft. Manganese nodules have washed dow nhill from the terraces to form $\mathrm{small}$ wash deposits in several places, mostly north of the roadless areas.

Some of the larger excavations for residual manganese or iron deposits are described below.

\section{Cardens Bluff mine}

The earliest iron mining near the areas was probably at the Cardens Bluff mine (loc. 7, fig. 2). Lim onite and goethite were produced from an open cut and shafts in yellow residual clay.

The Cardens Bluff mine was reopened for m anganese (loc. 8 , fig. 2), and a large open cut ylelded psilomelane and pyrolusite from residual clay. Manganese float $w$ as reported on a ridge crest southwest of the mine (King and others, 1944; loc. 5, fig. 2).
Exploration of the C. A. Blevins property on the ridge east of the Cardens Bluff mine in 1954 by Tennessee Manganese Corp., and in 1956 by Virginia Iron, Coal, and Coke $\mathrm{Co}_{0}$, delineated a minable manganese deposit (U.S. Forest Service, written commun., 1981), but no mining was done.

\section{Carden prospect}

The Carden prospect (loc. 2, fig. 2) w as explored at various times prior to 1941 . Three cuts were made in residual clay containing hard $m$ anganese oxide nodules. In $1941,3.6$ long tons of manganese concentrates were produced (King and others, 1944).

\section{Teaster and Ray prospect}

The Teaster and Ray prospect (loc. 4, fig. 2) includes two open cuts and several prospect pits. First exploration was in 1918; in 1936, 5 long tons of manganese concentrates were produced (King and others, 1944; Bitar and others, 1985). Exa mination of the workings during the present study revealed pockets and lenses of hard manganese oxide nodules and of wad. Similar material was exposed in two older pits nearby.

\section{Lim onite Ore Bank}

The Lim onite Ore Bank (1oc. 10, fig. 2) workings parallel the strike of the bedrock and consist of two trenches extending into open cuts. An unknown amount of iron ore was produced from residual clay between 1907 and 1909.

\section{Mineral deposits in Preca m brian rocks}

Several types of mineral deposits have been explored in the Precambrian rocks, both in the southeastern part of the roadless areas and especially west and southeast of the $\mathrm{m}$. The com modities sought in these deposits were fron, uranium, and thorium. The present study disclosed, in the same area, unusual amounts of $\mathrm{Hin}$, nfobium, beryllium, tungsten, fluorite, and topaz. Minerals containing niobium and rare earths were found in place in a shear zone. All of these metals and minerals $m$ ay have been emplaced by the sa me episode of mineralization.

\section{Magnetite-he matite prospects}

Several iron-ore prospects in Precambrian granitic rocks south and southeast of the roadless areas (Bayley, 1923; Ha milton, 1940; fig. 2) were explored from about 1890 to 1912 . The ore consisted of hematite, magnetite, or a mixture of both. No important iron deposits were found, but the prospecting showed black iron oxides to be a widespread product of mineralization.

The Whitehead prospect is on a ridge crest near the southern boundary of the Pond Mountain Addition Roadless Area (loc. 28, fig. 2). Bayley (1923) reported a thickness of $4 \mathrm{ft}$ of flinty, blue-gray hematite, and granite containing a mixture of magnetite and he $m$ atite.

At the Miller prospect (loc. 21, fig. 2), surface and underground workings revealed crushed quartz syenite and crushed diorite containing magnetite, hornblende, and small veins of epidote and quartz. No 
commercial fron deposits were discovered, and the work was abandoned (Bayley, 1923).

other magnetite and hematite occurrences include the Black Bear, Blacks, Rabbit Station, Mays Ridge, and Lunsford prospects; Finney and Teegarden mine; and an unnamed prospect (locs, 15-20 and 26, fig. 2).

\section{Thorlum and uranium deposits}

Previous investigators reported only minor a mounts of thorium and uranium minerals in veins and pegmatites in Precambrian granitic rocks near the roadless areas (locs. 14, 22-25, 29, and 30, fig. 2). Vein occurrences include reported "skarn" on Walnut Mountain that contains 0.09 percent $\mathrm{U}_{3} \mathrm{O}_{8}$ (Wagener and $\mathrm{McHone}, 1980$ ) and anomalous concentrations of thorium and uranium at the Walnut Mountain, Goodwin Field Branch, and Laurel Gap prospects (S. W. Maher, Tennessee Division of Geology, oral commun., 1981). 0 ccurrences in peg $m$ atite include reported radio m etric readings of four to ten tim es background values at the Dennis Cove prospect (Southern Interstate Nuclear Board, 1969), 0.021-0.15 percent $\mathrm{U}_{3} \mathrm{O}_{8}$ at the Row Branch prospect, and $0.057-0.22$ percent $\mathrm{U}_{3} \mathrm{O}_{8}$ at the Big Flats Branch prospect (Stow, 1955).

A reconnaissance radiometric survey of the Precambrian crystalline rocks conducted during this study indicated that the total background radiation is 150-300 counts per second. Anomalies of two to three times background were detected in some granite and gneiss exposures. Higher radioactive anomalles of three to five times background were detected in the shear zone that contains ultramylonite and altered granitic rock.

Radiometric and fluorometric analyses of ultramylonite samples indicated an average of about $160 \mathrm{ppm}$ thorium and $30 \mathrm{ppm}$ uranium. The analyses revealed slightly anomalous thorium and uranium values in all granitic rock samples, A highly weathered phyllonite sample having radiation of three times background contained $79 \mathrm{ppm}$ thorlum and 13 ppm uranium.

Investigation of the Walnut Mountain prospect showed radiation of two to three times background. Analysis of medium-grained, veined granite indicated only $40 \mathrm{ppm}$ thorium and $5 \mathrm{ppm}$ uranium. Coarsegrained granite samples from the Laurel $\mathrm{Gap}$ and Goodwin Fleld Branch prospects contained $7 \mathrm{ppm}$ thorium and 46 and $12 \mathrm{ppm}$ uranium, respectively. Petrographic and X-ray microprobe examinations of samples of granite indicate that thorlum and uranium are in monazite, thorite, and euxenite. other accessory minerals include bastnaesite, xenotime, apatite, and zircon.

A little iron prospecting was done near a large fault zone south of W atauga Point (loc. 11, fig. 2). A pit 7-10 ft deep and 10-20 ft wide was excavated in sheared and fractured rock; veins developed along the fractures, one of which was 2-3 in. wide and contained uraniu $\mathrm{m}$, thoriu $\mathrm{m}$, niobiu $\mathrm{m}$, and rare-earth ele ments (s. W. Maher, Tennessee Division of Geology, oral commun., 1982).

New Jersey Zinc Co., and $\mathrm{H} \& \mathrm{H}$ Co. opened several other prospects near the roadless areas. A mong these, the Goodwin Field Branch and Laurel Gap prospects (locs. 22 and 23, fig. 2) were reported to be vein deposits (S. W. Maher, oral commun, 1982). Radioactive pegmatite outcrops were reported at the
Dennis Cove prospect (Southern Interstate Nuclear Board, 1969) and at the Big Flats Branch and Row Branch prospects (Stow, 1955; locs. 14, 29, and 30, fig. 2).

Pechiney Ugine Kuhlmann Development, Inc., held uranium prospecting permits in the roadless areas from 1976 to 1979. Examination by this company of reported radioactive anomalles revealed no significant uraniu $m$ deposits.

\section{Deposits of niobium with rare metals}

Shear zone deposits

D uring this investigation, Bitar and others (1985) mapped cataclastic rocks along a shear zone in the headwaters of Firescald and Big Branches that contain unusual a mounts of nioblu $m$ and rare earths. The shear zone, typified by distinctive outcrops of ultra mylonite and by radiometric anomalles in residual soils, trends northwest, about normal to thrust faults bordering regional allochthons. Observed dips range fro $m 45^{\circ}$ to $60^{\circ}$ to the northeast.

Ultramylonite, the core of the shear zone, is bounded by alternating layers of granite, altered granite, and phyllonite. X-ray fluorescence analysis of 15 ultra m ylonite sa mples indicated an average niobiu $\mathrm{m}$ content of about 0.1 percent. Niobium is rather uniformly distributed along the length of the ultramylonite body. Petrographic and X-ray microprobe analyses revealed that niobium occurs in columbite, fergusonite, euxenite, and pyrochlore in a matrix of finely brecciated quartz and iron-rich muscovite. Other minerals include zircon, thalenite, thorium- and nonthorlum-bearing monazite, thorite, bastnaesite, and cerianite. He matite, in fine-grained clusters of grains and in fracture fillings, is ubiquitous and imparts a faint, dark-red tinge to fresh ultra mylonite surfaces. Lim onite pseudomorphs after pyrite occur in clusters and thin bands.

Altered granite and phyllonite of the outer part of the shear zone have niobium contents that range from 0.005 to 0.104 percent. Chemical and petrographic analyses of green altered granite revealed that niobium-bearing and other accessory minerals are similar to those in the adjacent ultra m ylonite but in $\mathrm{sm}$ aller a mounts.

Vein deposits

Two rare-metal occurrences were found near Walnut Mountain by regional uranium and thorium prospecting. Both occurrences are veins along fractures or foliation.

A vein at localtty 24 (fig. 2) was described by Wagener and McHone (1980) as an altered zone of follated granite containing medium-grained skarn. They reported that the $\mathrm{m}$ aterial contained 0.2 percent niobium, 0.2 percent yttrium, 0.1 percent zirconium, and 0.02 percent lanthanum. No skarn was found here during our study. However, 0.08 percent gadolinium, 0.04 percent tin, $6 \mathrm{ppm}$ tungsten, and $26 \mathrm{ppm}$ beryllium were detected in a sa mple of follated granite.

Niobium and rare-earth elements were also detected in a 2-3-in.-wide vein at the Walnut Mountain prospect (loc. 25, fig. 2) (S. W. Maher, Tennessee Division of Geology, oral com mun, 1982). 


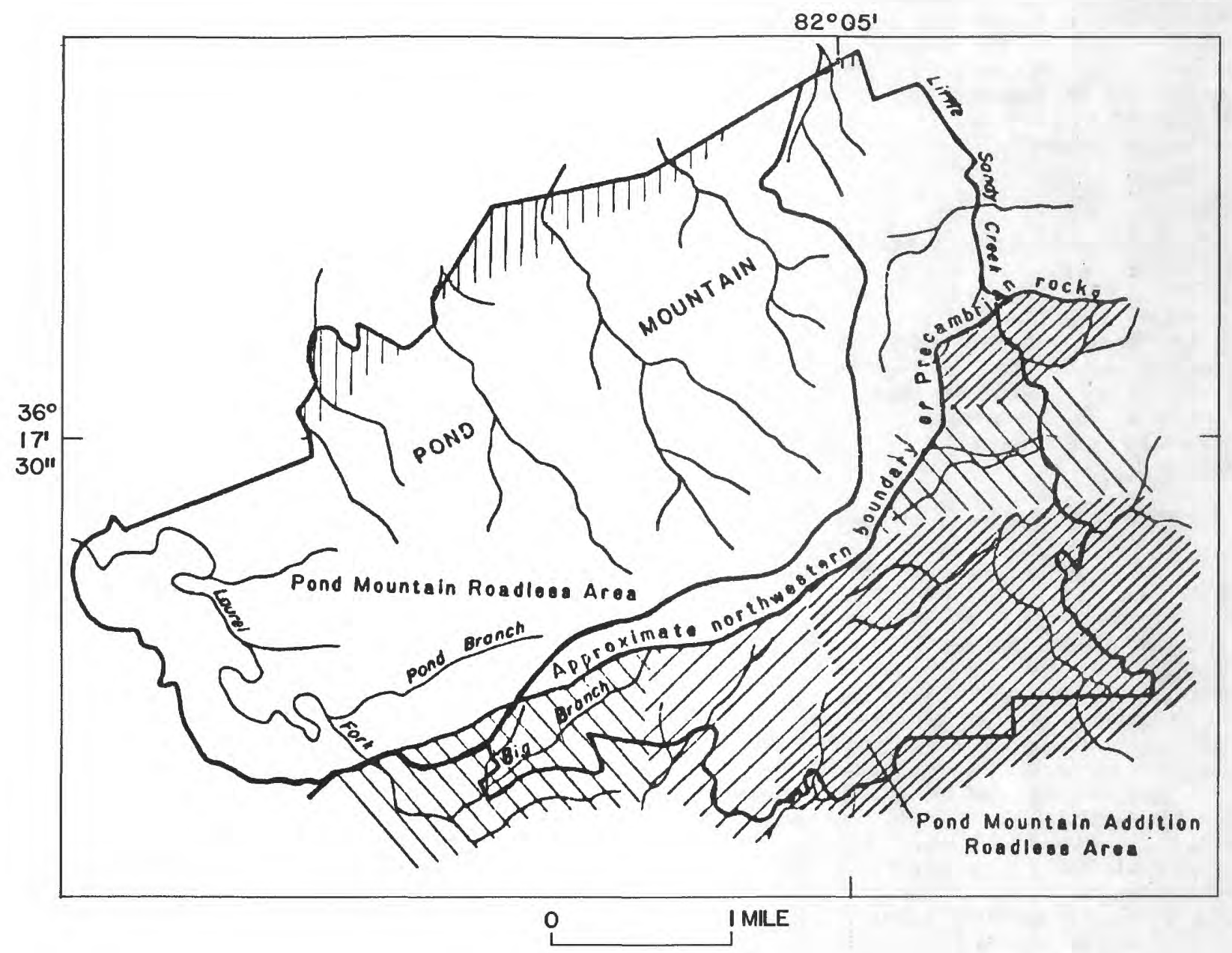

EXPLANATION OF RESOURCE POTENTIAL

The presence of three or more commoditles in the group tin. iungsten, niobium, fluorite, and topaz indicates high resource potential; the presence of two indicates moderate potential, and the presence of one indicates low potential.

HIGH RESOURCE POTENTIAL

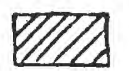

Tin, tungsten, and niobium

MOOERATE RESOURCE POTENTIAL

27 rin, tungsten, and niobium
LOW. RESOURCE POTENTIAL

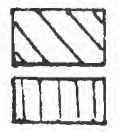

Tin, tungsten, and niobium

Manganese and iron

Figure 3.--Map showing mineral resource potential in the Pond Mountain and Pond Mountain Addition Roadless Areas, Carter County, Tennessee. 
Placer deposits of nioblu m, tin, zirconium, rareearths, thoriu $\mathrm{m}$, and uranium minerals $\mathrm{m}$ ay exist in the roadless areas. High concentrations of niobium, tungsten, tin, beryllium, and rare earths, and lower concentrations of thorium and uranium, were detected in panned concentrates. The rare earths are in m onazite, bastnaesite, xenotime, and euxenite.

\section{Sand and stone}

Stone for local road construction w as provided by the sandstone quarry in the Unicoi Formation, a $\mathrm{small}$ granite quarry, and a small sandstone quarry in the Erwin Form ation (locs. 13, 27, and 31, fig. 2). None of these quarries have been operated in recent years. A sand pit, also inactive (loc. 32 , fig. 2 ), is in weathered rock of the Hesse Quartzite. Operations were terminated because, at shallow depth, the rock became too hard to crush for sand (S. W. Maher, oral com mun, 1982).

\section{ASSESS MENT OF MINERAL RESOURCE POTENTIAL}

\section{Resources in crystalline rocks}

Within the roadless areas, the Preca $\mathrm{m}$ brian rocks were mineralized, and the intensity of mineralization in a particular area is indicated by the number of ore metals and minerals in the group consisting of tin, tungsten, niobium, fluorite, and topaz. The presence of three or more of these com modities indicates high resource potential, the presence of two indicates moderate potential, and the presence of one indicates low potential (fig. 3). Zinc, molybdenum, or beryllium commonly accompany these metals and minerals (Duttweiler and others, 1987) but were not used in classifying the mineral resource potential of any areas. Most of the Pond Mountain Addition Roadless Area has low to high resource potential for tin, tungsten, and niobium. A small part of the Pond Mountain Roadless Area has low resource potential for tin, tungsten, and niobium.

A mineralized shear zone that crosses Big Branch and Firescald Branch near their heads was studied in detail. Having an average thickness of $6 \mathrm{ft}$ and a length of $3,750 \mathrm{ft}$, it contains, above altitude $3,040 \mathrm{ft}$, about 17.5 million cubic feet, or 1.5 million short tons of rock. The estimated a mounts of various metals in this body are given in table 1 .

\section{Resources in residual $\mathrm{m}$ aterial}

Areas having potential resources of $m$ anganese and iron along the northern boundary of the Pond Mountain Roadless Area are (1) remnants of prominent terraces that are underlain by Shady Dolomite and (2) hillslopes mantled with colluvium below the terraces. Estim ates of resources are based only on lumps of hard manganese oxides in the clay, even though small masses of soft pyrolusite and wad in the deposits were sought during early mining because of their high manganese content. The resource potential is low for $\mathrm{m}$ anganese and iron in $\mathrm{sm}$ all areas in the northern part of the Pond Mountain Roadless Area.
Clay, sand, and stone are present in the roadless areas. Clay might be a byproduct of the mining of residual manganese ore. Sand deposits are too $\mathrm{sm}$ all for practical exploration, and stone is overlain by extensive weathered overburden and has no advantage over deposits that are closer to major markets.

Table 1.--Nlobium and other rare metals in a mineralized shear zone in Pond Mountain Addition Roadless Area, Tennessee

\begin{tabular}{|c|c|c|}
\hline Metal & $\begin{array}{c}\text { Grade } \\
\text { (percent) } 1\end{array}$ & $\begin{array}{l}\text { Amount } \\
\text { ( } \mathrm{n} \text { millions of } 1 \mathrm{bs} \\
\text { of contained metal) }\end{array}$ \\
\hline Niobium........... & 0.1 & 3.1 \\
\hline Tantalum.......... & .01 & 0.31 \\
\hline Zirconium......... & .36 & 11 \\
\hline Yttrium........... & .06 & 1.8 \\
\hline Ytterbium......... & .03 & 0.92 \\
\hline rnn............. & .05 & 1.5 \\
\hline Thorium........... & .016 & 0.49 \\
\hline Urani um........... & .003 & 0.09 \\
\hline
\end{tabular}

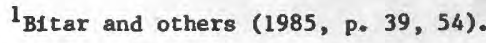

\section{REFEREN CES}

Bayley, W. S., 1923, The magnetic iron ores of east Tennessee and western North Carolina: Tennessee Division of Geology Bulletin 29, 252 . p.

Bitar, R. F., Behum, P. T., Ham mack, R. W., and Chat $m$ an, M. L., 1985, Minerals investigation of Pond Mountain and Pond Mountain Addition RA RE II Further Planning Areas, Carter County, Tennessee: U.S. Bureau of Mines Open-Fille Report MLA 8-85, 54 p.

Duttweiler, K. A., Griffitts, W. R., Cooley, E. F., and Whitlow, J. W., 1987, Geochemical map of the Pond Mountain and Pond Mountain Addition Roadless Areas, Carter County, Tennessee: U.S. Geological Survey Miscellaneous Field Studies Map M F-1648-B, scale 1:24,000.

H a milton, S. H., 1940, Report on the iron ore bodies of Carter County, Tennessee, and Avery County, North Carolina, contiguous to eastern Tennessee and Western North Carolina Ratlload: unpublished flle material for War Minerals Reports, avallable at U.S. Bureau of Mines, Intermountain Field operations Center, Denver, C 0,68 p.

King, P. B., and Ferguson, H. W., 1960 [1961], Geology of northeastern most Tennessee, with a section on Description of the basement rocks, by Warren Hamilton: U.S. Geological Survey Professional Paper $311,136 \mathrm{p}$.

King, P. B., Ferguson, H. W., Craig, L. C., and Rodgers, John, 1944, Geology and manganese deposits of northeastern Tennessee: Tennessee Division of Geology Bulletin 52, 275 p.

Southern Interstate Nuclear Board, 1969, Uranium in the southern United States: U.S. Atomic Energy Com mission W ASH-1128, 230 p. 
Stow, H. M., 1955, Report of the radiometric reconnaissance in Virginia, North Carolina, eastern Tennessee, and parts of South Carolina, Georgia, and Alabama: U.S. Atomic Energy Com mission report $R \mathrm{ME}-3107,33 \mathrm{p}$.

Taylor, R. G., 1979, Geology of tin deposits: A msterdam, Elsevier Scientific Publishing Co., $543 \mathrm{p}$.
W agener, H. D., and $\mathrm{McH}$ one, J. G., 1980, U ranium mineralization in the wilson creek and Cranberry gneisses and the Grandfather Mountain Formation, North Carolina and Tennessee: South Portland, Maine, Chiasma Consultants, Inc., 25 p. 
